\title{
PERCEPTIONS OF EDUCATION LECTURERS IN THE IMPLEMENTATION OF MOBILE LEARNING
}

\author{
Hendra Yulisman \\ Universitas Pendidikan Indonesia, Indonesia, hendrayulisman@student.upi.edu
}

\begin{abstract}
The rapid development of mobile and wireless communication technology has had a great impact on education. Previous researchers have implemented mobile device-assisted learning that is known as mobile learning. Mobile learning offers new opportunities for educators and learners in attempt to improve their quality of teaching and learning. However, mobile learning is still rarely used. One of the factors that influence it is that the teachers are still reluctant to implement mobile learning. In fact, the successful implementation of mobile learning is strongly influenced by the positive perception of its users. Therefore, it is very important to know the perception of the education lecturers. The aim of this study is to investigate the background and perception of educators in mobile learning. The method used in this study was descriptive method with qualitative approach. The data were collected from education lecturers who teach in Universitas Syiah Kuala by means of questionnaires and interviews. The results show that education lecturers in Universitas Syiah Kuala had positive perceptions of mobile learning. Interestingly, although they are not from ICT-related education, they are currently working with the ICT-related job and interested in implementing mobile learning. The financial and device issues were not to be the obstacles for the lecturers to integrate mobile learning in their class and most of them are ready to implement mobile learning before 2 years.
\end{abstract}

Keywords: Education lecturers, Mobile learning, Perception.

\section{INTRODUCTION}

The rapid development of mobile and wireless communication technology has had great impact on education, especially on the design concept of learning activities (C.-H. Chen, Chou, \& Huang, 2016; Hung, Hwang, Lin, Wu, \& Su, 2013; G. J. Hwang, Wu, Zhuang, \& Huang, 2013). Previous researchers have implemented the concept of learning activities based on mobile and wireless communication technology known as mobile learning ( $\mathrm{m}$ - learning). Mobile learning offers new opportunities for students to increase the engagement, motivation, and quality of their learning (Ahmed \& Parsons, 2013).

The application of mobile learning method is better than One Laptop per Child method. The advantages of mobile learning lie in the cost of infrastructure and maintenance, ease of use, the required equipment to implement mobile learning system (Buckner \& Kim, 2014) and make teaching and learning activities to be more dynamic (Callum, Jeffrey, \& Kinshuk, 2014). The implementation of mobile learning only requires a 
single computer that serves as a server, one or two routers, and mobile devices according to the number or needs of students (Buckner \& Kim, 2014).

Moreover, the availability of mobile learning content is another advantage of mobile learning. Mobile learning app content is vast, diverse, and growing rapidly (Buckner \& Kim, 2014). At the moment, there are over 5 million apps are available on iTunes and over 3 million on Google Play Store (Shuler, 2012), where educational apps are in Top Android app categories (AppBrain, 2017). The growth of mobile learning content is influenced by the rapid development of mobile device technology (G. J. Hwang et al., 2013) and the ease of application development of mobile learning. The mobile learning applications and the available content help the students in obtaining information (Ahmed \& Parsons, 2013; Buckner \& Kim, 2014; Hung et al., 2013; G. J. Hwang et al., 2013; Powell \& Mason, 2013; Song, 2014). Students can access the information whenever and wherever they need it. The ease of access to information known as seamless learning (Ahmed \& Parsons, 2013; G.-J. Hwang \& Chen, 2016; Song, 2014).

Mobile learning can be applied to various levels of education. Several studies have shown that mobile learning can be applied to basic, intermediate, and college students. This is due to the use of mobile devices that are a key factor of mobile learning is a very common use of today's society (G. J. Hwang et al., 2013; Marty et al., 2013; Song, 2014). However, with all its advantages, mobile learning is still rarely used nowadays (B. Chen, Seilhamer, Bennett, \& Bauer, 2015). One of the factors that influence it is that the teachers are still reluctant to implement mobile learning (Callum et al., 2014), only 30 percent of teachers who integrate mobile learning into learning assessment, while 55 percent of them prohibit the use of mobile devices in the classroom (B. Chen et al., 2015).

Teacher Training and Education Faculty of Universitas Syiah Kuala is one of campus that produce future teachers in Aceh, Indonesia. Students and prospective teachers were taught by education lecturers. The education lecturers, in addition, to teach about knowledge values, they are also expected to apply pedagogical values in their classroom. Furthermore, the successful implementation of mobile learning is strongly influenced by the positive perception of its users (Callum et al., 2014). Therefore, it is very important to know the perception of the education lecturers, because perception can affect their willingness and readiness in the implementation of mobile learning (Yusri, Goodwin, \& Money, 2015).

The purpose of this study is to investigate the background and perception of education lecturers towards implementation mobile learning in their teaching activity. Information obtained from this study it will be used as a basis to design and to develop a mobile learning system for education teachers in Indonesia, especially in Aceh province

\section{METHODOLOGY}

The participants of this research consist of seventy-eight educational lecturers from Teacher Training and Education Faculty, Universitas Syiah Kuala. They were participants in debriefing and preconditioning activities of PLPG 2017 program and will become an instructor for the teachers through PLPG program. One of the activities in this program is to improve the ICT skill of the lecturers. The ICT skill is a part that can improve the professionalism of a lecturer. Therefore, their perceptions of ICT, which in this research narrowed to the use of mobile learning, it is important to investigate. This study uses a questionnaire adapted from (Hussin, Manap, Amir, \& Krish, 2012; Yusri et al., 2015). This questionnaire consists of two parts, the first part related to lecturer data and the second part consists of questions related to backgrounds of work and education as well as perceptions of education lecturers on mobile learning. The second part of the questions consists of work and education backgrounds issue, knowledge on mobile learning issue, learning method issues, device issues, finance issues, and readiness in implementing mobile learning issue. The questionnaires were scored based on five-point Likert scale, with 1 representing strongly disagrees and 5 representing strongly agree. For negative items, the scoring was reversed, with 1 representing strongly agree and 5 representing strongly disagree. The questionnaires distributed through a web page and accessible via computer and smartphone.

\section{FINDINGS}

\subsection{Lecturers' Data}

The participants consist of $64 \%$ male and $36 \%$ female (Table 1). Furthermore, $78 \%$ of participants are master graduates, while the rest (22\%) are doctoral graduates. This is in accordance with the results of interviews with the instructor of the activity, which states that many lecturers who follow this activity are young lecturers who have passed the selection while the old lecturers (doctoral graduates) prefer not to follow the activities. 
Table 1. Lecturers' data and background

\begin{tabular}{|l|c|c|}
\hline \multicolumn{1}{|c|}{ Teacher data and background $(\mathrm{N}=78)$} & Frequency & Percentage (\%) \\
\hline Gender & 50 & 64 \\
Male & 28 & 36 \\
Female & & \\
\hline Educational background & 61 & 78 \\
Master & 17 & 22 \\
Doctoral & & \\
\hline Teaching Subject & 1 & 1 \\
Education & 8 & 10 \\
Bahasa education & 5 & 6 \\
English education & 2 & 3 \\
Guidance and counselling education & 6 & 8 \\
Biology education & 7 & 9 \\
Economy education & 6 & 8 \\
Physics education & 3 & 4 \\
Geography education & 14 & 18 \\
Primary school teacher education & 3 & 4 \\
Physical education, health, and recreation & 5 & 6 \\
Civics education & 5 & 6 \\
Chemistry education & 12 & 15 \\
Mathematics education & 1 & 1 \\
History education & & \\
\hline
\end{tabular}

Based on their teaching subject, the largest number of participants was primary school teacher education lecturers $(18 \%)$, mathematics education lecturers $(15 \%)$, and Bahasa lecturers $(10 \%)$. While the rest consists of the lecturers from education (1\%), English education (6\%), guidance and counselling education (3\%), biology education (8\%), economy education (9\%), physic education (8\%), geography education (4\%), physical education, health, and recreation (4\%), civics education (6\%), chemistry education (6\%), and history education (1\%). The number of lecturers based on the number of participants (teachers) who will attend the PLPG activities at that stage.

\subsection{Lecturers' Perceptions}

Table 2 shows the feedback given by lecturers regarding the implementation of mobile learning in the learning activities. This table consists of six sections. The first section relates to work and education background of the lecturers, this section consists of three statements. In the first statement, $44.9 \%$ of participants showed strongly agree or agree that their previous education related to ICT. Furthermore, $29.4 \%$ of participants have the education that not related to ICT. In the second statement, more than half of participants $(53.9 \%$ voted strongly agree or agree) had a history of work related to ICT, $27 \%$ of whom voted disagree or strongly agreed, meaning their previous work was not related to ICT. In the third statement, the majority of participants (82\% voted strongly agree or agree) works with the help or related to ICT, very few (3.9\% choosing disagree or strongly disagree) that works without dealing with the help of ICT. These results show that although their education does not come from ICT-related education, their current work related to ICT.

The second section of this table related to knowledge on mobile learning. In the first statement, nearly all participants $(93.6 \%)$ had knowledge of mobile learning. In the second statement, $96.2 \%$ of participants 
choose strongly agreed and agreed, which meant that most of them wanted to learn more about mobile learning. Furthermore, only $2.6 \%$ of participants did not interested in mobile learning. In the third statement, $93.6 \%$ of the participants believe that mobile learning can help improve their professionalism. In the fourth statement, as many as $89.8 \%$ of participants considered mobile learning not to burden them, this is related to previous statements, where mobile learning can even help improve their professionalism. Furthermore, 3.9\% of participants thought mobile learning would complicate their lives. In the last statement of this section, $69.2 \%$ of participants agree that mobile learning can save their learning time, that is, they can easily obtain certain information through mobile learning. Only $11.6 \%$ of participants considered mobile learning cannot save their learning time.

The third section of this table deals with learning issues. This section consists of five statements. The first statement of this section shows that $62.8 \%$ of participants prefer mobile learning over conventional learning and only $6.4 \%$ of participants prefer conventional learning rather than mobile learning. From the second statement, the majority of participants $(91 \%)$ want their instructor to integrate mobile learning into their learning activities. In the third statement, $80.8 \%$ of participants expect their instructors to integrate mobile learning into their learning besides to the use of online forums. The fourth statements that states mobile learning is an alternative to the web-based learning, $97.4 \%$ of participants agreed with the statement. In the last statement, some participants $(53.9 \%$ of participants voted strongly agree and agree) who consider mobile learning an alternative to conventional learning, $33.3 \%$ of participants considered mobile learning not an alternative to conventional learning.

Table 2. Lecturers' work and education background as well perception on mobile learning

\begin{tabular}{|c|c|c|c|c|c|c|}
\hline No. & Statements & SA (\%) & $A(\%)$ & $\mathbf{N}(\%)$ & D (\%) & SD (\%) \\
\hline \multicolumn{7}{|c|}{ Work and education background } \\
\hline A1 & $\begin{array}{l}\text { My previous education was related to } \\
\text { ICT }\end{array}$ & 14.1 & 30.8 & 25.6 & 25.6 & 3.8 \\
\hline A2 & My previous work was related to ICT & 15.4 & 38.5 & 19.2 & 24.4 & 2.6 \\
\hline A3 & $\begin{array}{l}\text { My current job is related to the use of } \\
\text { ICT }\end{array}$ & 39.7 & 42.3 & 14.1 & 2.6 & 1.3 \\
\hline \multicolumn{7}{|c|}{ Knowledge of mobile learning } \\
\hline B1 & I know about mobile learning & 34.6 & 59 & 6.4 & 0 & 0 \\
\hline B2 & $\begin{array}{l}\text { I want to know more about mobile } \\
\text { learning }\end{array}$ & 57.7 & 38.5 & 1.3 & 1.3 & 1.3 \\
\hline B3 & $\begin{array}{l}\text { I think mobile learning is great for } \\
\text { workers that want to learn new skill for } \\
\text { their professional development }\end{array}$ & 50.0 & 43.6 & 5.1 & 1.3 & 0 \\
\hline$B 4^{*}$ & Mobile learning will make my life difficult & 2.6 & 1.3 & 6.4 & 51.3 & 38.5 \\
\hline B5 & $\begin{array}{l}\text { Mobile learning will save my learning } \\
\text { time }\end{array}$ & 20.5 & 48.7 & 19.2 & 9 & 2.6 \\
\hline \multicolumn{7}{|c|}{ Learning method issues } \\
\hline $\mathrm{C}^{*}{ }^{*}$ & $\begin{array}{l}\text { I prefer conventional learning than } \\
\text { mobile learning }\end{array}$ & 0 & 6.4 & 30.8 & 50 & 12.8 \\
\hline $\mathrm{C} 2$ & $\begin{array}{l}\text { I would like my instructor to integrate } \\
\text { mobile learning into my training/course } \\
\text { in addition to face-to-face meetings }\end{array}$ & 24.3 & 66.7 & 9 & 0 & 0 \\
\hline
\end{tabular}


IJAEDU- International E-Journal of Advances in Education, Vol. III, Issue 9, December 2017

\begin{tabular}{|c|c|c|c|c|c|c|}
\hline C3 & $\begin{array}{l}\text { I would like my instructor to integrate } \\
\text { mobile learning besides online forum in } \\
\text { my training }\end{array}$ & 21.8 & 59 & 19.2 & 0 & 0 \\
\hline C4 & $\begin{array}{l}\text { Mobile learning is an alternative to web- } \\
\text { based learning }\end{array}$ & 34.6 & 62.8 & 2.6 & 0 & 0 \\
\hline C5 & $\begin{array}{l}\text { Mobile learning is an alternative to } \\
\text { conventional learning }\end{array}$ & 15.4 & 38.5 & 12.8 & 21.8 & 11.5 \\
\hline \multicolumn{7}{|c|}{ Device issues } \\
\hline D1 & $\begin{array}{l}\text { I want to know how to use my mobile } \\
\text { phone to be used in mobile learning }\end{array}$ & 23.1 & 57.7 & 7.7 & 7.7 & 3.8 \\
\hline D2 & $\begin{array}{l}\text { I will upgrade my mobile phone if mobile } \\
\text { learning is going to be implemented }\end{array}$ & 24.4 & 60.3 & 11.5 & 0 & 3.8 \\
\hline D3* & $\begin{array}{l}\text { I think I am not ready for mobile } \\
\text { learning using my mobile phone } \\
\text { facilities at this time }\end{array}$ & 0 & 6.4 & 21.8 & 43.6 & 28.2 \\
\hline \multicolumn{7}{|c|}{ Financial issues } \\
\hline E1 & $\begin{array}{l}\text { I don't mind paying extra money for } \\
\text { mobile learning }\end{array}$ & 12.8 & 41.0 & 34.6 & 9 & 2.6 \\
\hline $\mathrm{E}^{*}$ & $\begin{array}{l}\text { I was worried I would spend more } \\
\text { money on my mobile phone bill for } \\
\text { mobile learning }\end{array}$ & 1.3 & 15.4 & 34.6 & 32.1 & 16.7 \\
\hline \multicolumn{7}{|c|}{ Readiness on mobile learning } \\
\hline $\mathrm{F} 1^{*}$ & $\begin{array}{l}\text { I don't think I want to be involved in } \\
\text { mobile learning }\end{array}$ & 0 & 1.3 & 6.4 & 56.4 & 35.9 \\
\hline $\mathrm{F}^{*}$ & $\begin{array}{l}\text { I am not ready for mobile learning right } \\
\text { now }\end{array}$ & 0 & 1.3 & 11.5 & 55.1 & 32.1 \\
\hline F3 & $\begin{array}{l}\text { I will be ready for implementing mobile } \\
\text { learning after } 2 \text { years }\end{array}$ & 0 & 15.4 & 17.9 & 46.2 & 20.5 \\
\hline
\end{tabular}

*negative statements

Legend: SA = Strongly Agree; $A$ = Agree; $N$ = Neutral; $D$ = Disagree; SD = Strongly Disagree

The fourth section of the above table relates to devices issues. This section consists of three statements. In the first statement, $80.8 \%$ of the participants were interested in learning how to use their mobile phones in mobile learning and $11.5 \%$ of the participants were not interested in using their mobile phones for mobile learning. The result from the second statement in this section is very interesting, this statement relates to the willingness of the lecturers to upgrade their mobile phone if mobile learning implemented. The results show that $84.7 \%$ of participants will upgrade their mobile phone if mobile learning is applied, only $3.8 \%$ of participants will not do it. The final statement of this section shows that $71.8 \%$ of participants believe that their telephone facilities have been able to accommodate mobile learning. This is in accordance with one of the advantages of mobile learning because it can be applied to various types of smartphone (Song, 2014). Furthermore, only $6.4 \%$ of participants thought their mobile phones could not be used in mobile learning.

The sixth section of the table contains two statements. This section related to financial issues. The results of the first statement showing a portion of the participants (53.8\%) had no hesitation to spend additional costs in the implementation of mobile learning and $11.6 \%$ of the participants objected to spending extra money for 
the implementation of mobile learning. Furthermore, $48.8 \%$ of the participants were not worried about mobile billing in the implementation of mobile learning and $16.7 \%$ of the participants were worried about mobile billing expenses in the implementation of mobile learning.

The last section of the table relates to the readiness on mobile learning. This section consists of three statements. The first statement about participation in mobile learning. The results show that $92.3 \%$ of participants voted strongly disagrees or disagree, meaning that most of them wanted to be involved in implementing mobile learning. Only $1.3 \%$ of them choose not to get involved. In the second statement, $87.2 \%$ of participants voted strongly disagree or disagree, which means that most of them are ready for the implementation of mobile learning. Furthermore, $1.3 \%$ of participants showed their unpreparedness in mobile learning. In the last statement, most of the participants (66.7\% chose strongly disagree and disagree) indicated they were ready to integrate mobile learning in less than two years. Only $15.4 \%$ of participants took more than two years to be able to integrate mobile learning.

\section{CONCLUSION}

The education lecturers in FKIP Universitas Syiah Kuala had positive perceptions of mobile learning and they were looking forward to integrating mobile learning into their teaching and learning activity. Interestingly, although they are not from ICT-related education, they are currently working with ICT-related and interested in implementing mobile learning. The financial and device issues were not to be the obstacles for the lecturers to integrate mobile learning in their class and most of them are ready to implement mobile learning before 2 years. These findings will be used as baseline data in designing and developing a mobile learning system for education teachers in Indonesia, especially in Aceh province.

\section{ACKNOWLEDGEMENT}

I would like to take this opportunity to express my profound gratitude and deep regard to the Indonesia Endowment Fund for Education (LPDP) for taking part in providing me with financial support to finish this paper. I would like to show my warm thank to Dr. Ismul Huda, M.Si., who supported me at every bit and without whom it was impossible to accomplish this research. It is such a great honor for me to be guided by him. I also want to express my sincere gratitude to my wife, Cut Intan Evtia Nurina who helped, supported, and encouraged me while I conducted this research. Without her meaningful comments, advice, and assistance, this study could not have been completed. I would also like to give my sincere gratitude to all lecturers who filled in the survey, without which this research would be incomplete.

\section{REFERENCE LIST}

Ahmed, S., \& Parsons, D. (2013). Abductive Science Inquiry Using Mobile Devices in The Classroom. Computers \& Education, 63, 62-72. doi:http://dx.doi.org/10.1016/i.compedu.2012.11.017

AppBrain. (2017). Google Play Stats. Retrieved from https://www.appbrain.com/stats

Buckner, E., \& Kim, P. (2014). Integrating Technology and Pedagogy for Inquiry-based Learning: The Stanford Mobile Inquiry-based Learning Environment (SMILE). Prospects, 44(1), 99-118. doi:10.1007/s11125-013-9269-7

Callum, K. M., Jeffrey, L., \& Kinshuk. (2014). Factors Impacting Teachers' Adoption of Mobile Learning. Journal of Information Technology Education: Research, 13, 141-162.

Chen, B., Seilhamer, R., Bennett, L., \& Bauer, S. (2015). Students' Mobile Learning Practices in Higher Education: A Multi-Year Study. Retrieved from http://er.educause.edu/articles/2015/6/studentsmobile-learning-practices-in-higher-education-a-multiyear-study

Chen, C.-H., Chou, Y.-Y., \& Huang, C.-Y. (2016). An Augmented-Reality-Based Concept Map to Support Mobile Learning for Science. Asia-Pacific Edu Res, 25(4), 567-578. doi:10.1007/s40299-016-0284-3

Hung, P.-H., Hwang, G.-J., Lin, Y.-F., Wu, T.-H., \& Su, I.-H. (2013). Seamless Connection between Learning and Assessment: Applying Progressive Learning Tasks in Mobile Ecology Inquiry. Educational Technology \& Society, 16(1), 194-205.

Hussin, S., Manap, M. R., Amir, Z., \& Krish, P. (2012). Mobile Learning Readiness among Malaysian Students at Higher Learning Institutes. Asian Social Science, 8(12), 276-283. 
doi:http://dx.doi.org/10.5539/ass.v8n12p276

Hwang, G.-J., \& Chen, C.-H. (2016). Influences of an Inquiry-based Ubiquitous Gaming Design on Students' Learning Achievements, Motivation, Behavioral Patterns, and Tendency Towards Critical Thinking and Problem Solving. British Journal of Educational Technology, Early View. doi:10.1111/bjet.12464

Hwang, G. J., Wu, P. H., Zhuang, Y. Y., \& Huang, Y. M. (2013). Effects of The Inquiry-based Mobile Learning Model on The Cognitive Load and Learning Achievement of Students. Interactive Learning Environments, 21(4), 338-354. doi:http://dx.doi.org/10.1080/10494820.2011.575789

Marty, F, P., Douglas, I., Sampson, V., Alemanne, N., Mendenhall, A., . . Schellinger, J. (2013). The Iterative Design of a Mobile Learningn Application to Support Scientific Inquiry. Journal of Learning Design, 6(2), 338-354.

Powell, C. B., \& Mason, D. S. (2013). Effectiveness of Podcasts Delivered on Mobile Devices as a Support for Student Learning During General Chemistry Laboratories. J Sci Educ Technol, 22(2), 148-170. doi:10.1111/j.1365-2729.2010.00390.x

Shuler, C. (2012). iLearn II: An Analysis of the Education Category on Apple's App Store. Retrieved from The Joan Ganz Cooney Center at Sesame Workshop: http://joanganzcooneycenter.org/publication/ilearn-ii-an-analysis-of-the-education-category-onapples-app-store/

Song, Y. (2014). "Bring Your Own Device (BYOD)" for Seamless Science Inquiry in A Primary School. Computers \& Education, 74, 50-60. doi:http://dx.doi.org/10.1016/i.compedu.2014.01.2015

Yusri, I. K., Goodwin, R., \& Money, C. (2015). Teachers and mobile learning perception: towards a conceptual model of mobile learning for training. Procedia - Social and Behavioral Sciences, 176(20 February 2015), 425:430. doi:doi.org/10.1016/j.sbspro.2015.01.492 